\title{
Between Trauma and Resilience
}

\section{A Transnational Reading of Women's Life Writing about Wartime Rape in Germany and Bosnia and Herzegovina}

\author{
Agatha Schwartz and Tatjana Takševa
}

\begin{abstract}
This article discusses the personal narratives (both published and personal interviews collected for the purpose of this study) of female survivors of wartime rape in postWorld War II Germany and postconflict Bosnia and Herzegovina. The authors examine how the women succeed in finding their words both for and beyond the rupture caused by the rapes through examples of life writing that challenge the dominant masculinist historical narrative of war created for ideological reasons and for the benefit of the nation-state. Using theories of trauma and insights by feminist scholars and historians, the authors argue that a transnational reading of survivors' accounts from these very different geopolitical and historical contexts not only shows multiple points of mutual influence, but also how these narratives can make a significant contribution, both locally and globally, when it comes to revisiting how wartime rape is memorialized, and how lessons learned from the two contexts can be relevant and applicable in other situations of armed conflict as well.
\end{abstract}

KEYWORDS: agency, memory, narratives of women survivors, trauma, wartime rape

In this article, through the narratives of women survivors we explore the effects and transgenerational consequences of rape during two twentieth-century episodes of armed conflict: the end of World War II in Germany and the war in Bosnia and Herzegovina (former Yugoslavia), 1992-1995. While the rapes in World War II had received little public attention until a few decades ago, the Bosnian mass rapes elicited largescale international attention leading to long-overdue changes in international law and policies regarding sexual violence in conflict that used to be a 'forgotten' war crime. ${ }^{1}$ The rapes in Bosnia also brought renewed attention to the controversial topic-given Germany's guilt in World War II and the Holocaust—of the mass rape of German women at the end of World War II, and contributed to the development of broader 
social discourses around sexual violence in conflict. While rape in war has received increased scholarly attention since second-wave feminism with respect to other countries and historical contexts as well, ${ }^{2}$ our comparison offers a unique contribution to the understanding of its consequences because it is based on selected women survivors' narratives from the two specific historical episodes-Germany and Bosnia-highlighting their transnational connections. Although these two episodes are separated by over half a century and belong to distinct geopolitical and cultural contexts, feminist scholars have pointed out connections with respect to their interpretation: "There are strong parallels between the two cases, both in the ideology of the rapes and in the ensuing feminist discourse, that allow them to elucidate each other in unexpected ways." ${ }^{\prime 3}$

Our analysis will further emphasize the parallels between these two episodes of mass rape by comparing the expressions of trauma and resilience in the survivors' narratives and elucidating connections between them, and the way the two episodes of war rape have mutually shaped the memory and discourse around the rapes. Thus, the focus of our analysis is how the narratives and their respective contexts have transgressed their national boundaries and made an impact beyond the local level. Within this framework of analysis, "what we need to investigate are the mechanisms by which memories are (trans)formed, displayed, shared, and negotiated through transnational channels, while maintaining their local rootedness. ${ }^{\prime \prime}$ Our analysis contributes to a better understanding of: (1) the ways women formulate their sexual violation and their resilience; (2) how they and their respective communities remember wartime sexual violence; (3) what their communities can do to recognize the harm done to the survivors and to facilitate their recovery; and (4) how the survivors' narratives can potentially shape a re-evaluation of the dominant historical discourses about war toward reconciliation and peace building. Finally, we also address the transgenerational consequences of the rapes through children born of this violence.

From the German context, we use three published diaries/memoirs. As no such narratives have been published to date from the Bosnian context, we rely on our own interviews recently conducted with Bosnian rape survivors. Both these very personal narrative expressions fall under the umbrella term of "life writing." ${ }^{5}$ Margit Sutrop explained: "Life writing ... is deeply rooted in our responsibilities to remember." ${ }^{\text {A }}$ As pointed out by Ruth Seifert, history written by male historians tends to treat rape in wars as an "isolated phenomenon," with the consequence that historical memory is largely informed by a masculinist perspective erasing women's traumatic experiences. Our transnational reading of women's life writing about war and sexual violence will contribute to reintegrating women's voices in the creation of historical memory. ${ }^{8}$

We ground our analysis in theories of trauma. For Suzette A. Henke, life writing may help reinvent the self and reconstruct the traumatized fragmented subject, as it leads to narrative recovery of a past traumatic experience, thereby restoring a sense of agency shattered through the trauma. ${ }^{9}$ We explore the posttraumatic narrative process of the construction of a meaningful self, and how this process is put in motion with the help of transnational channels.

Memorializing and narrating wartime rape has been a challenging task. Ann E. Kaplan reminds us that people who lived through a catastrophe may need to forget the traumatic experience because it is too difficult in the immediate aftermath to deal 
with; ${ }^{10}$ but she distinguishes between this "temporary forgetting" and an "engineered forgetting" of dominant groups, which amounts to another act of violence-through silence and intentional forgetting. Kaplan also challenges Cathy Caruth's verdict about the "unspeakability" of trauma. In stark contrast, Kaplan argues that by telling and sharing traumatic memories, a certain "working through" and healing of traumatic memory can happen. Joanna Bourke and Ann Cvetkovich ${ }^{11}$ have both pointed to the exclusion of women's experiences, particularly in the context of sexual violence, and how large-scale traumatic events such as war implicate the nation-state as a masculinist structure with a vested interest in creating and then disavowing the trauma suffered by women. Our transnational reading of the German and Bosnian narratives about war rape allows us to engage with the gendering of historical memory while elucidating the duality between women's silencing and their resilience and agency as they formulate their stories.

\section{Historical Context}

Wartime rape has long been downplayed as a by-product of war. ${ }^{12}$ Second-wave feminism identified rape as an act of violence conducted through sexual means with the aim to destroy the "respectability" of the enemy nation, a symbolic battlefield carried out on women's bodies. In recent cases (e.g. Bosnia, Rwanda), rape has been recognized as a strategy of ethnic cleansing and a tool of genocide. ${ }^{13}$ The effects of these rapes on the women themselves, including the lasting trauma for many, have often been overlooked. Only recently, largely due to the systematic rapes in Bosnia in the 1990s, has the focus shifted somewhat to emphasize the damage done to women's well-being. According to Selma Leydesdorff: "Of all the painful and destructive aspects of war, rape is second only to mass murder in its devastation of a society and of the women who are scarred by it."14

The number of women raped in conflict, including World War II, will likely remain an estimate given the complex issue of memorializing rape in war and the mechanisms of silence that surround rape as a phenomenon, but historians talk about millions of women affected both in Nazi-occupied territories and in territories liberated/ occupied by the Allies. ${ }^{15}$ Without downplaying genocidal rape and other atrocities committed by German armed forces in Europe and the former Soviet Union, ${ }^{16}$ Miriam Gebhardt's recent study drew attention to the fact that, against long-held assumptions, not only the Red Army but also the Western Allies committed mass rapes against German women. ${ }^{17}$ Marianna G. Muravyeva confirms that "mass rape was not unique to the Soviet army during the Second World War."18 Estimates of German rape victims fluctuate between $860,000^{19}$ and two million, ${ }^{20}$ but as Norman Naimark cautions: "It is highly unlikely that historians will ever know how many German women were raped by Soviet soldiers in the months before and years after the capitulation." 21 According to Antony Beevor, about 10 percent of the women raped in Berlin alone died of the consequences, many by committing suicide, whereas in parts of Nazi Germany further east, the death rate is considered to be higher. ${ }^{22}$ Most of the survivors are no longer with us; and few had the courage or chance to tell their stories while alive. 
In addition to the "unspeakability" of the traumatic experience, there were additional reasons behind German rape survivors' silence. The rapes were ideologically manipulated on the Cold War political playground. Following the division of Germany in 1949, in the Soviet occupation zone that became East Germany (the GDR), discussing any ill deeds committed against German civilians by the Red Army quickly became taboo. In West Germany, the political right instrumentalized the rapes by the Soviets as part of a German narrative of victimhood and anti-Soviet propaganda, ${ }^{23}$ while rapes by Western Allies were swept under the carpet. On both fronts, women's narratives told in their own voices were unwelcome for decades to come. The women who suffered the violence never received any official recognition or compensation. ${ }^{24}$ In the words of Elisabeth Krimmer: "When wartime rape is made to serve an ideological agenda, as it often is, the experience of the victim, her trauma and pain, threaten to disappear amidst the noise of justifications, metaphors, and political deployments." ${ }^{25} \mathrm{It}$ took decades and another episode of mass rape in a nearby country in Europe to bring about a re-evaluation of these experiences and to encourage some of the remaining survivors to tell their stories.

The connection between wartime rape and representational practices serving ideological purposes became evident in the case of the war in Yugoslavia. Dubravka Žarkov has convincingly demonstrated the direct engagement of the media of the former Yugoslav republics in forging nationalist politics in the 1980s, which resulted in the construction of ethnic differences as the main basis for the 1990s conflict. ${ }^{26}$ Gender and sexuality norms contributed to this representational practice aimed at radicalizing ethnic difference. Women's physical bodies, be it in relation to childcare, abortion rights, or population growth, were discursively manipulated toward the production of radical nationalist body politics. The media of each republic thus created an ideological link between words and the deeds that those words came to describe. ${ }^{27}$

It was not long after the Yugoslav conflict erupted (1991) that stories of widespread sexual violence against "enemy" women started to be reported in the Western media. By 1992, Bosnia became one of the deadliest regions in the world. Under the banner of the old Yugoslav army, all sides (Serb, Croat, and Muslim) but particularly Serbian nationalist forces engaged in campaigns of ethnic cleansing of Bosnians of Muslim faith and ethnic heritage, also called Bosniaks (Bošnjaci). It became clear that a significant aspect of this strategy involved the systematic use of genocidal rape and enforced impregnation of primarily Bosniak women. ${ }^{28}$ When Roy Gutman of Newsday reported in July 1992 that he witnessed sexual violence in a concentration camp in Manjača, the subject exploded internationally. The term "rape camps," first used in international reporting, suggested that these were not random acts of violence. The camps were put up often in empty buildings, even schools and hotels like the infamous Vilina Vlas hotel in Višegrad. ${ }^{29}$ Mostly young women and teenage girls were exposed to sexual enslavement, torture, and even murder. It is estimated that between 25,000 and 40,000 Bosniak women were victims of genocidal rape, and many of them of enforced impregnation as well, released from the camps only after their pregnancies had progressed beyond the possibility of a safe abortion. ${ }^{30}$ In this conflict, as in previous ones, including the rape of German women at the end of World War II, it was evident that women's bodies were treated as "an essential instrument of male war strategy." ${ }^{131}$ The 
rapes represented once again a form of gendered projection of the national body that justified its manipulation and "ownership," as well as violence against it on a political, physical, and representational level.

\section{Narratives by German Rape Survivors}

Since German rape victims in most cases kept silent about their ordeal, post-World War II narratives about the rapes (formulated by historians or eyewitnesses) mostly emphasized their resilience and attempt to move on, which fell within the dominant discourse of rebuilding the country in the 1950s both in East and West Germany. The image of the strong German woman willing to make sacrifices for her family and homeland dominated during the following decade as well. ${ }^{32}$ This element of resilience ${ }^{33}$ is present in the widely translated diary by Anonymous, A Woman in Berlin, in which a young educated woman offers a firsthand account of the siege of Berlin by the Red Army from the perspective of a rape survivor. It was first published in English in 1954 and only in 1959 in the German original after several other translations. ${ }^{34}$ Reception in the author's country was more than chilling to the point that she refused any further editions. New editions, along with a film by the same title, came out posthumously in the new millennium. ${ }^{35}$ The narrator's resilience is expressed on multiple levels: she refuses to give in to despair; she helps other women; she finds herself a "protector" (a high-ranking officer) to keep away the raping Soviet soldiers; she brings "gallows humor" into her writing; and, finally, writing the diary itself becomes a form of "scriptotherapy," 36 allowing her to write herself through and out of the traumatic experiences. Anonymous's diary thus illustrates what Zur Nieden said about German women's wartime diaries: "The authors of the diaries do not search for a truth without interest, but rather orientation, relief and safety." 37

However, the narrator's resilience and desire to take control over her life cannot erase the fact that her body and mind were traumatized by multiple rapes. She admits to being bruised, shaken, and nauseated, and unable to enjoy sexual closeness with her partner when he returns from the war: "I'm numb. Not with disgust, only cold. My spine is frozen: icy, dizzy showers around the back of my head. I feel myself gliding and falling, down, down, through the pillows and the floorboards. So that's what it means to sink into the ground." ${ }^{38}$ For young girls, for whom the rapes were their first sexual experience, the violence and dehumanization were so traumatizing that some contemplated suicide. The will to survive, however, triumphs in the narrator's words of encouragement to the other women: "I'm alive, aren't I? Life goes on!"39

Although this internationally known narrative about wartime rape has no translation in Bosnian/Serbian/Croatian, ${ }^{40}$ the diary and the homonymous film by German filmmaker Max Färberböck in 2008 became well-known in the successor states of former Yugoslavia, including Bosnia. For example, in 2007, a literary evening was organized in Sarajevo with the French translator of the book, which testifies to an interest in this narrative and the fate of German rape survivors in Bosnia. ${ }^{41}$

Two narratives by German rape survivors who were teenagers during the war further clarify the effects of trauma caused by the rapes. Gabi Köpp only went public 
with her story in 1992, and a new, revised edition was published in 2010, in the same year that Leonie Biallas published a revised version of her memoir. ${ }^{42}$ Both authors address the trauma of being raped and gang-raped by Soviet soldiers as fifteen- and fourteen-year-old girls, respectively. In addition to feelings of shame and humiliation, Köpp speaks of exhaustion, nausea, fear, nightmares, emotional numbness, and her period stopping for seven years, while Biallas, in addition to losing her period for seven months, also suffered painful symptoms of an STD. Köpp's narrative is based on her diary, which she kept during her flight. Although she had a successful postwar academic career in West Germany as a physics professor-which speaks to her resilience-she kept silent about her violation for decades; her little notebook became a family taboo. Similar to Köpp, who decades later sought therapy before publishing her narrative, Biallas also never talked to anybody about "it," not even to her mother, who was both a victim of rape and a witness to her daughter's rapes. Biallas kept silent for decades, until she found her first "empathetic listener"43 in her supportive husband. Incorporating her memories as a meaningful part of her life resulted in going public with her story.

These examples of life writing speak to both the silencing of German women's personal narratives about their violation and their courage to challenge what Kaplan termed "engineered forgetting." For Köpp and Biallas, their mothers acted as gatekeepers and ensured their daughters' silence, while Anonymous clearly reveals male control over women's narratives of war. When her partner, Gerd, returned from the battlefield, he not only did not become an "empathetic listener," but also harshly judged her and the other women for their agency and resistance to being reduced to "bare life." 44 This silencing of women, instrumentalized for political purposes, also served to reconstruct the traumatized masculinity and defeat of German men, the "trauma of male disempowerment." ${ }^{45}$ At the same time, however, it prevented the work of memory and mourning for decades. ${ }^{46}$ Anonymous refused to have her diary republished during her lifetime; and it took both Köpp and Biallas decades to muster up the courage to publish their stories. Although there are no direct references to the rapes in Bosnia, Birgit Beck-Heppner, in her afterword to Köpp's book, makes this transnational connection between the two episodes of mass rape clear: "A working through of the events [in Germany] only followed in connection with what happened during the civil war in former Yugoslavia. It brought the topic of sexual violence in wars again to public attention and in addition, led to an intensive study of this phenomenon." 47

In recent years, Svenja Eichhorn and Philip Kuwert conducted a research project on elderly German women raped in World War II, concluding that persons who had traumatic experiences in their youth (such as war rape) may demonstrate symptoms of retraumatization in old age triggered by exposure in the media to images of similar trauma. ${ }^{48}$ The extensive media coverage of the Bosnian war in the 1990s, German publications about the rapes, ${ }^{49}$ and German aid workers' active involvement with raped Bosnian women (e.g., Dr. Monika Hauser, founder of the organization medica mondiale $)^{50}$ had that effect on some German rape survivors. For some, the shock that women were facing yet again the same violence in Europe, only a few decades after the terrible war they lived through, triggered a coming-out with their stories, and they were finally able to become active agents in finding a "vocabulary of rupture" 51 for their 
suppressed traumatic memories. Unfortunately, far too many German women took their stories with them. It is thus all the more important for Bosnian rape survivors to tell their stories and for the world to listen to them, rather than allow their voices to suffer a similar fate. This fear is expressed by one of the Bosnian survivors in her interview: "We are starting to languish, we will disappear. I only regret that we won't leave our mark in time." 52

\section{Narratives by Bosnian Rape Survivors}

The proverbial wall of silence has been a reality in the case of many Bosnian rape survivors. Most of them have chosen not to speak out about their experience due to fear of blame and social stigma attached to rape itself in Bosnian society and to them as victims. ${ }^{53}$ Medica Zenica, a therapy center in the Bosnian town of Zenica, records having helped hundreds of women over the last two decades. But, in their 2014 report they note that only fifty-one survivors who have used their services since 1993 agreed to be interviewed for the purposes of this particular study the results of which were published in a 173 page document, concluding that "questions about how those women who never seek help feel about and cope with their experiences remain unanswered." ${ }^{54}$ A significant factor contributing to women's reluctance to speak is the awareness that their voices can be and often are appropriated, manipulated, and exploited. The meanings produced through representational practice and their connection to the masculinist meaning produced by the actual violence are visible in the media's approach to the survivors' sexually violated bodies. In a recent interview, Gabriela Mischkowski, cofounder of medica mondiale in Bosnia, notes: “Once the fighting actions decreased, more and more journalists came from all over the world and they all wanted to speak with women who had been sexually attacked ... At the beginning they used to speak quite openly with journalists, but they (or many of them) soon realized that they were being used, that their stories were being distorted and the need to speak rapidly turned into a silence." ${ }^{55}$ Subsequently, Bosnian women have expressed suspicion not only of journalists but also of researchers "willing to make PhDs on the topic of wartime violence." 56 Their responses highlight the need for sensitive participatory research methodologies that enable multiple forms of agency and emphasize respectful human interaction. While research and media coverage of sexual violence during the conflict contributed to increased visibility for the victims and growing international awareness leading to new legal frameworks of justice, they also often led, from the perspective of the survivors, to the reproduction of harmful clichés and the distortion of their narrative agency.

In this sense, it is understandable that the number of survivors who choose to speak out-like in the German case-is statistically small. However, precisely because of the highly contested arena of public representation and transitional justice, their actions and words are extremely significant in relation to three areas: the system of international justice that extends beyond Bosnia; the social discourse surrounding sexual violence in war within Bosnia; and the individual benefits for the survivor and her family. The relationships among these three areas intersect with the level of support 
offered to and accepted by individual survivors. Community and social levels of support, at least in theory, should flow out of human rights discourses and international legislation, and should facilitate the development of community-embedded policy and practice aimed at long-term rehabilitation of survivors. However, this is often difficult to implement. For Bosnian survivors, the relationship among speaking out, recognition, and acceptance across the three areas is complex and fraught with tension.

From a feminist perspective of international law and human rights, the significance of the proceedings of the International Criminal Tribunal for the former Yugoslavia (ICTY, 1993-2017) was that for the first time wartime rape was included among crimes against humanity. Although historically there has been an awareness of sexual violence against women in war, at past international courts it was not classified under crimes against humanity or linked to genocide. Alongside the ICTY, the International Criminal Tribunal for Rwanda (ICTR, 1994-2015) played a "pioneering role in the establishment of a credible international criminal justice system. ${ }^{\prime \prime 7}$ These tribunals have "forever changed the landscape of international justice" ${ }^{\prime 58}$ because among their verdicts are, for the first time, convictions for rape and sexual enslavement, as well as the first definition in international criminal law of rape as a means of perpetrating genocide. ${ }^{59}$ The ICTY's famous Foča trial was the first one of its kind resulting in convictions for rape, torture, and sexual enslavement as crimes against humanity. The significance of the new legal frameworks established by the ICTY and the ICTR cannot be overstated and constitute a new direction in approaching sexual violence in conflict.

The piecing together of "vocabularies of rupture" for Bosnian women survivors has to begin by acknowledging the remarkable courage and resilience of those who agreed to appear as witnesses both locally and in The Hague, and to speak out for the first time in the presence of the perpetrators. By speaking out they literally ruptured the silence that historically surrounds the wartime rape of women. Breaking this silence also contributes to unmasking rape mythologies and victim blaming. Speaking out means using their voices to denounce the crimes they suffered and to participate actively in the creation of the politics of memory. Such politics as well as the performative act itself, as Antonio Sousa notes, "effectively transposes the often long-silenced individual suffering to the public conscience and responsibility" and transforms testimony into a "constitutive element of public discourse." ${ }^{160}$ Bosnian women's testimonies have reclaimed the voices of female rape survivors that are still omitted from or manipulated in the male-dominated public discourses around the Bosnian conflict. Their agency has also encouraged others to speak the truth with some faith that their voices will contribute to justice. Women's agency and resilience is manifested paradoxically through their willingness to name and narrate the experience of their utmost victimization and dehumanization that stripped them at the time of their ability for self-direction and choice, which is the basis of agency. Agency and victimization thus emerge as two sides of their experience of trauma. As Judith Herman reminds us, "the conflict between the will to deny horrible events and the will to proclaim them is the central dialectic" of psychological trauma. ${ }^{61}$

In terms of social discourses surrounding sexual violence in war, the stories of primarily Bosniak women survivors contributed significantly to a growing consciousness of the pervasiveness of war rape, the suffering experienced by the women, and the 
genocidal nature of this type of violence. Lessons learned from their experiences told in their own voices have a truly transnational relevance, as we have seen in the German revival of interest in the World War II rapes. These testimonies have the potential to redefine "publicly the experience of rape from the victim's perspective, rather than from the perspective of the rapist and of law enforcement officials." ${ }^{\prime 2}$ They are just as relevant to understanding the experiences of women who have lived in conflict zones and experienced rape as part of enemy strategies in numerous other countries since. ${ }^{63}$ As well, awareness of the types of support offered to Bosnian survivors after the war-something German women and other women raped in World War II did not have-and the issues they continue to face socially and psychologically inform the approaches to peace building and the understanding of long-term consequences of war trauma related to sexual violence. At the same time, much remains to be done regarding the full social rehabilitation of survivors in Bosnia.

Conversations in the public arena tend to place the emphasis on what Elizabeth Swanson calls the "cultural significance of silence and voice," which is placed in "complex dialogue with the individual and psychological ones," instigating a collective as well as an individual questioning of the trope of "unspeakability" itself. ${ }^{64}$ It was clear to Takševa in her conversations with Bosnian women survivors that for all of them, in Swanson's words, the "reclamation of voice is also a gesture toward building subjectivities profoundly damaged in the foundational act and cultural consequences of wartime rape." ${ }^{\prime 65}$

The narratives from which we draw were collected in the form of open-ended, semistructured qualitative "life history interviews" 66 in 2017 in the Federation of Bosnia and Herzegovina during a month-long stay. Prior to the interviews, Takševa had contacted individuals and organizations who worked with survivors. Open-ended interview questions were provided beforehand, drafted by the research team for this project, and approved by both Schwartz's and Takševa's institutions' offices of research ethics. The Bosnian individuals and organizations provided the names and contacts of women survivors who were willing to be interviewed. All participants signed an informed consent form also approved by both institutions' offices of research ethics.

Takševa interviewed eight women survivors between the ages of 40 and 50, and eight leaders of nongovernmental organizations (NGOs) who shared their experiences regarding working with the survivors. As Takševa is originally from the former Yugoslavia and speaks the Bosnian language, no interpreter was needed, and she was also cognizant of the broader social and cultural context. Selected data from the interviews are used strictly according to the participants' consent and their wishes as to how they wanted or did not want to be identified and what information they wished to share publicly.

Each woman was given the freedom to shape the nature of the interview according to her own preference. Takševa invited and respected the women's exercise of agency regarding these choices. They were offered a monetary compensation for their willingness to take part in the interview, and all accepted. As part of polite social interaction and respect, this was negotiated through the NGO leaders before the interviews, rather than directly with the women, to protect their dignity. The women were invited 
to name the time and place of the interview. All survivors expressed interest in staying in touch and learning about the work that resulted from the conversations. This context strengthened and solidified the moral and ethical obligation the research team feels with respect to the representation of the women's narratives in subsequent work.

The significance and individual benefits of speaking out for the survivors and their families can be understood through the nature of the traumatic experience itself. The survivors all expressed that through the rape and torture they felt subhuman, similar to the German narratives, in addition to numerous, often lasting, consequences such as numbness, dissociation, and depression (among many other symptoms) that only began to subside following therapy. This means that one of the primary goals in posttraumatic recovery is to re-establish the survivors' markers of humanity, that is, self-direction, sense of control, positive view of the self, and self-respect. Narrating the difficult experience plays an important role in this healing process, as seen in the German narratives as well. Most of the women interviewed emphasized how important it is to talk about what they had been through, even if it may be difficult at times: "Only talking can heal you." 67 Research on trauma shows that the work of reconstruction through building new vocabularies helps transform traumatic memory and settle its physical and mental effects. Dominick LaCapra considers this "working through" of traumatic memory extremely important, as it enables survivors to redefine their lives in a meaningful way by allowing them to move beyond the past injury and distinguish between past and present and look toward building a future, a process that should not be equated with a "cure." 68 Working through traumatic memories helps the survivors regain ethical and political agency and control over the story of their traumatic past and move beyond the position of victim toward an agentive view of the self that feels proud rather than ashamed. Not all survivors undertake this slow, uneven process for a variety of reasons - as we could see in the German examples, and also addressed by Bosnian survivors. How to tell the story, to whom, and in what context is of great importance and interdependent with other forms of community and structural support, an element many Bosnian survivors unfortunately still lack.

Azra's (Azra is a pseudonym) story is one that illustrates well the interdependence of all three levels of significance when it comes to the agency involved in speaking out and its complex nature:

I was hesitating since I have not shared my story anywhere for a very long time. Last time I shared it, I was a witness in court, at The Hague . . . Not that I left it behind, it is always somewhere around, following you like a shadow ... But for a long time no one offered me, in this way, meaning that it is done discretely. So, I was hesitating . . . I will do it, I will not . . . and at the last minute I decided I will, maybe my small voice can be heard somewhere, in some body of research. So that is my only motive, that something is heard somewhere ... I understand that those women who spoke publicly helped all of us, but for the voice to be heard ... somehow everything is concentrated around these women. And somewhere because of that kind of thinking, I decided well, okay, let this small voice of mine be heard somewhere, in some book. And it will leave a trace and it might grab someone's attention sometimes, it does not 
have to be about me . . . if I help someone, I will be somehow glad. So these are some of my motives for talking. ${ }^{69}$

The interplay among the three levels of significance with respect to breaking the silence-the system of international justice, the social/community discourse of war rape, and individual benefits - is evident in Azra's narrative. She agreed to speak out at court to facilitate justice. Her subsequent desire for silence as well as the paradoxical urge to speak about her experience is captured in her reference to the women "who speak publicly." Even though these women have helped others with similar experiences, they have also taken the public's attention from women who do not wish to speak in public but who, nonetheless, would like to tell their story for their own benefit and the benefit of others. Here we witness Azra's own awareness of the act of telling as invested with agency and the power to shape public discourse and memory.

Azra's own vocabulary of rupture unfolds differently in different contexts and at different times: while she was one of the women who agreed to testify in court, she has not spoken about her experience to her family or her community, but decided to speak to Takševa when given the opportunity, after a decade of silence. When asked about why it is important to her to hide her experience from her community, she replied: "Because I don't want people to look at me through that . . . I know about the case of German women, I read about it and was really sorry and I know they opened up to talk only after so many years when Bosnian women started talking ... Because I do not want to be put in that role, no matter what happened, I do not want to be in the role of victim." 70 Azra's words illustrate that the reality of the decision to speak out is more complex than often assumed. Keeping the details of her violation from her family stems from a desire to protect them. However, her silence is also about not allowing her victimization to define her subsequent life. The decision not to make her experience known to her community is therefore based on her agentive shaping both of the perception others may have of her and of her life path that should not be reduced to what she experienced as a very young woman. Here keeping the silence, that is, deciding not to break it, is constitutive of her agency. At the same time, she also emphasizes the importance of having found an "empathetic listener" in Takševa and her team, who would be able to carry on her story and thus shape the discourse and memory around sexual violence. This need to have an "empathetic listener" is considered crucial in coping with trauma in other narratives as well: "Imagine if you couldn't talk to anyone, had to put up with it, bottle it up."71

Azra's words also indicate that she is aware of the narratives of German women, and that this knowledge also contributed to her decision to share her story. By rejecting the role of victim, Azra redefines the way in which she wishes to engage with the public - not as a victim, but as a narrator whose words both dispel the mythology surrounding rape and bestow dignity upon the survivor. Just like the German survivors who broke their silence, Azra helps shape the discourse surrounding war rape and the survivors themselves. This refusal to be reduced to the position of victim is echoed by other survivors as well as an expression of both resilience and a desire for justice: "I am not ashamed. I feel like a hero who overcame everything, who is alive and well ... To me justice is served by me being okay and brave, strong and showing them I'm alive."72 


\section{Toward a Transnational Memory of Wartime Rape}

As seen in the above examples, the attention the Bosnian rapes brought to the plight of German women and the resulting increase in public survivor testimony in Germany over the last two and a half decades suggests that such testimonies may contribute to the shifting of public discourse in Bosnia toward a more constructive engagement with the topic of sexual violence in war. For example, the 2015 publication of Gebhardt's book Als die Soldaten kamen (Crimes Unspoken, 2016), discussed above, captured the attention of some Bosnian news outlets. Several news stories and editorials summarized the book for Bosnian audiences, as well as provided interviews with the author. In one of those, Gebhardt is cited as saying: "The next step is to continue to think through gendered structures of power and violence against women, because that is at the heart of the issue. Mass rapes are still taking place in many conflict zones, such as, for example, those committed by terrorist groups like ISIS and Boko Haram." ${ }^{73}$ The interest of the Bosnian media in the subject is also evidenced, for example, by the May 2018 publication of an editorial about the rapes of two million German women and Stalin's approval of this type of violence. ${ }^{74}$ The article cites several recent books on the subject as well as excerpts from survivor testimonies, and makes the point that Milovan Djilas, a high-ranking Yugoslav politician and later dissident, is on record criticizing this form of warfare and questioning Stalin openly about it in his Conversations with Stalin. These examples indicate the presence of a transnational element regarding the topic of sexual violence during war in Bosnia as it pertains to the German context but that clearly has local relevance.

Further to the above examples of news coverage with respect to the rape of German women, on 11 July 2016, the Bosniak Institute in Sarajevo organized a book launch for Mi djeca okupacije (We children of the occupation) by Ute Baur-Timmerbrink. ${ }^{75}$ This book, published in the previous year in German and promptly translated into Bosnian, narrates the destinies of children fathered by Allied soldiers in Germany and Austria, whether through rape or in consensual relationships. Baur-Timmerbrink, herself a child of the occupation, provides an extensive background to the period between 1945 and 1955, when numerous children were fathered by members of the Soviet, US, British, and French occupation armies. ${ }^{76}$ Baur-Timmerbrink integrates the children's narratives into her own account about their psychosocial well-being over the span of several decades. ${ }^{77}$ By making public the stories of the children, now elderly adults, the book indirectly speaks to the experiences of the children born of war rape in Bosnia, and encourages the development of public discourse surrounding this forgotten and marginalized population. ${ }^{78}$

In 2015, the NGO Zaboravljena djeca rata (Forgotten children of the war) was founded in Sarajevo, with the aim of advocating for the rights of this group in Bosnia and lifting the stigma that often accompanies these now young adults and their mothers. Over the last years, this NGO has led a number of region-wide campaigns aimed at raising public awareness of the topic across the new post-Yugoslav nationstates, advocating for rights for the children of war and women survivors of all ethnic groups. We can thus see that the publications on the subject of German rapes and their consequences, along with the publicizing of these narratives in Bosnia, con- 
tributes positively to the development of local activism and education regarding the topic of sexual violence in war. By building a discourse of reconciliation and antidiscrimination, this kind of discourse foregrounds the benefits of speaking out on this difficult subject.

\section{Conclusion}

The harm rape in conflict carries for women and girls in particular (without taking away from the fact that men and boys too get raped in wars) ${ }^{79}$ cannot be emphasized enough. Our transnational reading of women's life writing about war rape demonstrates that the traumatic impact of the rapes often continues for a long time, especially when cemented behind a wall of silence. As shown in our analysis of the two episodes of wartime rape, it is evident that they have mutually contributed not only to a breaking of this silence but also to a potentially constructive shaping of the memory and social discourses around rape. The voices of the German survivors were suppressed for decades and instrumentalized for the purposes of projecting an image of the wounded national body, and it took another more recent episode of mass rape in a nearby country to trigger a re-evaluation of those experiences. A similar process is unfolding in Bosnia, where the discourse of victimization also plays a part in the politics of memory and the perpetuation of different versions of truth about the war and victimhood with the purpose of advancing separate ethnonationalist political agendas. Survivors' organizations themselves contribute to this "by building on the capital of the ethics of victimization." ${ }^{80}$ Some of these organizations, while doing valuable advocacy and providing essential services, also propagate a social narrative that idealizes victimhood. In both cases, the result is the silencing of the survivors themselves and foreclosing of much-needed opportunities for them to tell their stories and allow their voices to enter the public space on their own terms.

Reintegrating the survivors into their social networks is of utmost importance. This process becomes particularly difficult in a situation like postconflict Bosnia, where the women often have to live in the same community as their rapists. Andreas Hamburger's research on genocidal trauma reminds us how in a society where victims and perpetrators continue to live side by side a conspiracy of silence is established. ${ }^{81}$ Breaking this process becomes a key factor for healing, but it is very difficult. Therefore, in addition to adequate services and ongoing trauma counseling, offering survivors a safe space where they can formulate their own "vocabularies of rupture," move beyond their trauma, and define their own ways of accepting what happened to them will allow them not only to become active agents in their own healing process but also in the healing of their broken communities. The above examples of women's life writing about sexual violence in conflict work toward establishing an "archive of feelings." 82 Reading them through a transnational lens reminds us how necessary the integration of women's voices into official narratives and memories of war is in the process of peace building. These narratives contribute to raising awareness about the importance of changing societal attitudes of victim blaming. They also further the acknowledgment and understanding of the deep trauma rape leaves behind and how 
it affects multiple generations. They remind us of the necessity and urgency of further infusing this knowledge into the justice system so that it may benefit survivors of sexual violence in other contexts as well.

\section{$\diamond$ About the Authors}

Agatha Schwartz is Full Professor of German and World Literatures and Cultures at the University of Ottawa, Canada. Her research areas are nineteenth- to twentyfirst-century Central European literature and culture, women's writing, and narratives of trauma. Her books include Shaking the Empire, Shaking Patriarchy: The Growth of a Feminist Consciousness Across the Austro-Hungarian Monarchy (with Helga Thorson, 2014); Gender and Modernity in Central Europe: The Austro-Hungarian Monarchy and its Legacy (editor, 2010); and Shifting Voices: Feminist Thought and Women's Writing in Finde-Siècle Austria and Hungary (2008). Recent articles include "Haunting and the Aesthetics of Trauma in A Woman in Berlin and For Those Who Can Tell No Tales: Redefining Cultural Memory" (with Mythili Rajiva, Slavonica, 2018) and "Trauma, Resilience, and Narrative Constructions of Identity in Germans Born of Wartime Rape" (German Studies Review, 2020).

Tatjana Takševa is Associate Professor of English Language and Literature and Women's and Gender Studies at Saint Mary's University, Canada. She is a long-standing member of Motherhood Initiative for Research and Community Involvement, and a Demeter Press board member. She has published extensively in the area of motherhood studies, on subjects such as mothering and teaching, the commercialization of motherhood in Anglo-American contexts, the ideology of intensive mothering, and mother love and maternal ambivalence. Her ongoing research and publications involve mothering children born of rape on the territories of the former Yugoslavia and the construction of national and ethnic identity in women survivors of war rape and children born of war in the former Yugoslavia. She is the editor of Mothers Under Fire: Mothering in Conflict Areas, with Arlene Sgoutas (Toronto: Demeter Press, 2015).

\section{$\diamond$ Notes}

This work was supported by the Social Sciences and Humanities Research Council of Canada (SSHRC) under grant number 430-2016-00232, titled “'Children of the Enemy': Narrative Constructions of Identity Following Wartime Rape and Transgenerational Trauma in PostWWII Germany and Post-Conflict Bosnia," with Agatha Schwartz as principal investigator and Tatjana Takševa, Mythili Rajiva, and Christabelle Sethna as coinvestigators.

1. Rhonda Copelon, "Toward Accountability for Violence Against Women in War: Progress and Challenges," in Sexual Violence in Conflict Zones: From the Ancient World to the Era of Human Rights, ed. Elizabeth D. Heineman (Philadelphia: University of Pennsylvania Press, 2011), 232-256. Copelon notes that these resolutions still do not explicitly call for the prosecution of sexual violence, nor do they ensure that women be involved in postconflict decision-making processes. See also Sabine Lee, Children Born of War in the Twentieth Century (Manchester: Manchester University Press, 2017), 153. Efforts to end sexual violence in conflict continue. In 2015, the UN General Assembly proclaimed 19 June International Day for the Elimination of Sexual 
Violence in Conflict. The most recent UN resolution (April 2019) was watered down following the threat of a US veto over the question of survivors' reproductive rights.

2. Sexual violence against women has been documented in many different conflicts both before and after World War II. See Susan Brownmiller's classic Against Our Will: Men, Women, and Rape (New York: Ballantine Books, 1979). On the rape of Chinese women by Japanese forces, see Iris Chang, The Rape of Nanking: The Forgotten Holocaust of World War II (New York: Basic Books, 1997). On the rape of Hungarian women by Soviet soldiers, see Andrea Petö, Elmondani az elmondhatatlant: A nemi erószak története Magyarországon a II. világháború alatt [Speaking of the unspeakable: Sexual violence in Hungary in World War II] (Budapest: Jaffa, 2018). On the rape of Soviet women by German soldiers, see Regina Mühlhäuser, Eroberungen: Sexuelle Gewalttaten und intime Beziehungen deutscher Soldaten in der Sowjetunion, 1941-1945 [Conquests: Sexual violence and intimate relationships of German soldiers in the Soviet Union 1941-1945] (Hamburg: Hamburger Edition, 2010). On the rape of Austrian women by Soviet soldiers, see Barbara Stelzl-Marx, Stalins Soldaten in Österreich: Die Innensicht der sowjetischen Besatzung 1945-1955 [Stalin's soldiers in Austria: Soviet occupation from the inside, 1945-1955] (Vienna: BöhlauOldenbourg, 2012). On the rapes during the Indian partition, see Urvashi Butalia, The Other Side of Silence: Voices from the Partition of India (Durham, NC: Duke University Press, 2000). On the rape of Nigerian girls by Boko Haram, see Wolfgang Bauer, Die geraubten Mädchen: Boko Haram und der Terror im Herzen Afrikas [The kidnapped girls: Boko Haram and terror in the heart of Africa] (Berlin: Suhrkamp, 2016).

3. Pascale R. Bos, "Feminists Interpreting the Politics of Wartime Rape: Berlin, 1945; Yugoslavia, 1992-1993," Signs 31, no. 4 (2006): 995-1025, here 996.

4. Aline Sierp and Jenny Würstenberg, eds., "Transnational Memory Politics in Europe," special issue, Journal of Contemporary European Studies 23, no. 3 (2015): 321-446, here 324.

5. Paul John Eakin, ed., The Ethics of Life Writing (Ithaca, NY: Cornell University Press, 2004).

6. Margit Sutrop, “Afterword: Ethical and Political Aspects of Life Writing and Remembering," in Haunted Narratives: Life Writing in an Age of Trauma, eds. Gabrielle Rippl, Philipp Schweighauser, Tiina Kirss, Margit Sutrop, and Therese Steffen (Toronto: University of Toronto Press, 2013), 321-333, here 325.

7. Ruth Seifert, "War and Rape: A Preliminary Analysis," in Mass Rape: The War Against Women in Bosnia-Herzegovina, ed. Alexandra Stiglmayer (Lincoln: University of Nebraska Press, 1994), 54-72, here 66.

8. On the omission of women's voices from the writing of history, see Penny Summerfield, Reconstructing Women's Wartime Lives: Discourse and Subjectivity in Oral Histories of the Second World War (Manchester: Manchester University Press, 1998); and Miriam Gebhardt, Als die Soldaten kamen: Die Vergewaltigung deutscher Frauen am Ende des zweiten Weltkriegs (Munich: Deutsche Verlags-Anstalt, 2015), published in English as Crimes Unspoken: The Rape of German Women at the End of the Second World War, trans. Nick Somers (Cambridge: Polity Press, 2017).

9. Suzette A. Henke, Shattered Subjects: Trauma and Testimony in Women's Life Writing (New York: St. Martin's Press, 1998).

10. Ann E. Kaplan, Trauma Culture: The Politics of Terror and Loss in Media and Literature (New Brunswick: Rutgers University Press, 2005), 67.

11. Joanna Bourke, "Sexual Violence, Bodily Pain, and Trauma: A History," Theory, Culture and Society 29, no. 3 (2012): 25-51; Ann Cvetkovich, An Archive of Feelings: Trauma, Sexuality and Lesbian Public Cultures (Durham, NC: Duke University Press, 2003).

12. Barbara Kosta, "Rape, Nation and Remembering History," in Gender and Germanness: Cultural Productions of Nation, ed. Patricia Herminghouse and Magda Mueller (Providence, RI: Berghahn Books, 1997), 217-231, here 223. 
13. Rhonda Copelon, "Surfacing Gender: Reengraving Crimes Against Women in Humanitarian Law," in Women and War in the Twentieth Century: Enlisted With or Without Consent, ed. Nicole Ann Dombrowski (New York: Routledge, 1999), 245-266.

14. Selma Leydesdorff, Surviving the Bosnian Genocide: The Women of Bosnia Speak, trans. Kay Richardson (Bloomington: Indiana University Press, 2011), 22.

15. Raphaëlle Branche and colleagues point to the difficulty of establishing statistics of rape victims in war. See Raphaëlle Branche, Isabelle Delpla, John Horne, Pieter Lagrou, Daniel Palmieri, and Fabrice Virgili, "Writing the History of Rape in Wartime," in Rape in Wartime, eds. Raphaëlle Branche and Fabrice Virgili (New York: Palgrave Macmillan, 2012), 1-16, here 14.

16. See Mühlhäuser, Eroberungen; Regina Mühlhäuser, "Reframing Sexual Violence as a Weapon and Strategy of War: The Case of the German Wehrmacht during the War and Genocide in the Soviet Union, 1941-1944," Journal of the History of Sexuality 26, no. 3 (2017): 366-401.

17. Gebhart, Als die Soldaten kamen. All quotations from German sources were translated by Schwartz.

18. Marianna G. Muravyeva, "Categorising Rape in the Military Law of Modern Russia," in Branche and Virgili, Rape in Wartime, 17-33, here 30.

19. Gebhardt, Als die Soldaten kamen, 33.

20. Helke Sander and Barbara Johr, eds., BeFreier und Befreite: Krieg, Vergewaltigung, Kinder [Liberators take liberties: War, rape, children] (Berlin: Fischer, 1995).

21. Norman Naimark, cited in Atina Grossmann, "A Question of Silence: The Rape of German Women by Occupation Soldiers," October 72 (Spring 1992): 42-63, here 47.

22. Antony Beevor, The Fall of Berlin 1945 (New York: Penguin 2002), 410.

23. See Júlia Garraio, “Die deutsche Literatur und das Gedächtnis der sexuellen Gewalt im Zweiten Weltkrieg" [German literature and the memory of sexual violence in WWII], in Vom Experiment zur Neuorientierung: Forschungswege der Germanistik im 21. Jahrhundert [From experiment to new orientations: Research directions for German studies in the 21st century], eds. Ana Maria Bernardo, Fernanda Mota Alves, and Ana Margarida Abrantes (Berlin: Frank \& Timme, 2017), 35-51.

24. See Regina Mühlhäuser, “Vergewaltigungen in Deutschland 1945: Nationaler Opferdiskurs und individuelles Erinnern betroffener Frauen" [Rapes in Germany 1945: National discourse of victimhood and women's individual memories], in Nachkrieg in Deutschland [PostWorld War II in Germany], ed. Klaus Naumann (Hamburg: Hamburger Edition, 2001), 384-408.

25. Elisabeth Krimmer, German Women's Life Writing and the Holocaust: Complicity and Gender in the Second World War (Cambridge: Cambridge University Press, 2018), 114.

26. Dubravka Žarkov, The Body of War: Media, Ethnicity, and Gender in the Break-up of Yugoslavia (Durham, NC: Duke University Press, 2007), 3.

27. Ibid., 4 .

28. Although Bosniak women were the largest affected group and Serb forces the biggest perpetrators, all sides used rape as a strategy of war. Research indicates that Croatian and Serbian women in Bosnia were also sexually abused and subjected to forced impregnation, as confirmed by our interview participants as well. See Alexandra Stiglmayer, "The Rapes in Bosnia-Herzegovina," in Mass Rape: The War Against Women in Bosnia-Herzegovina, ed. Alexandra Stiglmayer (Lincoln: University of Nebraska Press, 1994), 82-169, here 137; Elissa Helms, Innocence and Victimhood: Gender, Nation and Women's Activism in Postwar Bosnia-Herzegovina (Madison: University of Wisconsin Press, 2013), 54.

29. On Vilina Vlas, see Mythili Rajiva and Agatha Schwartz, "Haunting and the Aesthetics of Trauma in A Woman in Berlin and For Those Who Can Tell No Tales: Redefining Cultural Memory," Slavonica, 12 December 2018, https://doi.org/10.1080/13617427.2018.1555923; Emma Graham-Harrison, "Back on the tourist trail: The hotel where women were raped and tortured," 
Guardian, 28 January 2018, https://www.theguardian.com/world/2018/jan/28/bosnia-hotelrape-murder-war-crimes. Višegrad is today located in Republika Srpska. Following the Dayton Peace Agreement (1995), Bosnia and Herzegovina, formerly a republic within Yugoslavia, was divided into the Federation of Bosnia and Herzegovina and the Republika Srpska, and the small Brčko District belonging to both entities.

30. See Beverly Allen, Rape Warfare: The Hidden Genocide in Bosnia Herzegovina (Minneapolis: University of Minnesota Press, 1996); Inger Skjelsbaek, "Victim and Survivor: Narrated Social Identities of Women who Experienced Rape During the War in Bosnia-Herzegovina," Feminism and Psychology 16 (2006): 373-402; Cindy Snyder, Wesley J. Gabbard, J. Dean May, and Nihada Zulcic, "On the Battleground of Women's Bodies: Mass Rape in Bosnia-Herzegovina," Affilia 21 (2006): 184-195.

31. Žarana Papić, "Women in Serbia: Post-Communism, War and Nationalist Mutations," in Gender Politics in the Western Balkans: Women and Society in Yugoslavia and the Yugoslav Successor States, ed. Sabrina P. Ramet (Pennsylvania: Penn State University Press, 1999), 153-171, here 156.

32. Miriam Gebhardt, "Eine Frage des Schweigens? Forschungsthesen zur Vergewaltigung deutscher Frauen nach Kriegsende" [A question of silence? Research theses on the rape of German women at the end of the war], in Besatzungskinder: Die Nachkommen alliierter Soldaten in Österreich und Deutschland [Children of the Allied occupation in Austria and Germany], ed. Barbara Stelzl-Marx and Silke Satjukow (Vienna: Böhlau, 2015), 62-90, here 69.

33. We use resilience following, on the one hand, Barbara Stelzl-Marx's definition as the ability "to take a positive development despite adverse circumstances," and on the other, Renee Linklater, who defines resilience as "the ability to withstand trauma and turmoil and be able to proceed with living and engaging in a productive life." See Barbara Stelzl-Marx, "'Ich bin stolz, ein Besatzungskind zu sein': Resilienzfaktoren von Nachkommen sowjetischer Soldaten in Österreich" ["I am proud to be a child of the occupation": Resilience factors in children fathered by Soviet soldiers in Austria], in Kinder des Zweiten Weltkrieges: Stigmatisierung, Ausgrenzung, Bewältigungstrategien [Children of the second world war: Stigmatization, marginalization, resilience], eds. Elke Kleinau and Ingvill C. Mochmann (Frankfurt: Campus, 2016), 73-92, here 73); and Renee Linklater, Decolonizing Trauma Work: Indigenous Stories and Strategies (Halifax: Fernwood Publishing, 2016), 25.

34. See Birgit Dahlke, “Tagebuch des Überlebens: Vergewaltigungen 1945 in ost- und westdeutschen Autobiographien" [Rapes in 1945 as per East and West German autobiographies], in Autobiography by Women in German, eds. Mererid Puw Davies, Beth Linklater, and Gisela Shaw (New York: Peter Lang, 2000), 195-212.

35. See Agatha Schwartz, "Narrating Wartime Rapes and Trauma in A Woman in Berlin," CLCWeb: Comparative Literature and Culture 17, no. 3 (2015), dx.doi.org/10.7771/1481-4374.2655.

36. Henke, Shattered Subjects, xii.

37. Susanne zur Nieden, Alltag im Ausnahmezustand: Frauentagebücher im zerstörten Deutschland 1943 bis 1945 [Women's diaries in destroyed Germany 1943-1945] (Berlin: Orlanda Frauenverlag, 1993), 28.

38. Anonymous, A Woman in Berlin, trans. Philip Boehm (New York: Picador, 2005), 64. We respect the author's wish to remain anonymous and refrain from using her name, which a disrespectful German journalist made public following her passing and the publication of the new edition of her diary.

39. Ibid., 59.

40. Bosnian, Serbian, and Croatian are the now politically divided variations of one language that before the war was called Serbo-Croatian.

41. "Književno selo: Jedna žena u Berlinu" [Literary discussion: A Woman in Berlin], 7 June 2007. 
42. Gabi Köpp, Warum war ich bloß ein Mädchen: Das Trauma einer Flucht 1945 [Why was I a girl: The trauma of a flight 1945] (Munich: Knaur, 2010); Leonie Biallas, "Komm, Frau, raboti": Ich war Kriegsbeute [“Woman come, work": I was a war booty] (Leverkusen: Drachenmond, 2010).

43. Shoshana Felman and Dori Laub, Testimony: Crises of Witnessing in Literature, Psychoanalysis, and History (New York: Routledge, 1992), 58.

44. Holger Pötzsch, "Rearticulating the Experience in War in Anonyma: Eine Frau in Berlin," Nordlit, no. 30 (2012): 15-32, here 22, http://www.academia.edu/2639420/Rearticulat ing_the_Experience_of_War_in_Anonyma_Eine_Frau_in_Berlin.

45. Barbara Kosta, "Rape, Nation and Remembering History," in Gender and Germanness: Cultural Productions of Nation, eds. Patricia Herminghouse and Magda Mueller (Providence, RI: Berghahn Books, 1997), 217-231, here 222.

46. Kosta, "Rape, Nation and Remembering History," 222.

47. Birgit Beck-Heppner, "Nachwort" [Afterword], in Köpp, Warum war ich bloß ein Mädchen?, 139-154, here 142.

48. Svenja Eichhorn and Philip Kuwert, Das Geheimnis unserer Großmütter: Eine empirische Studie über sexualisierte Kriegsgewalt um 1945 [Our grandmothers' secret: An empirical study on wartime sexual violence around 1945] (Gießen: Psychosozial-Verlag, 2011).

49. German journalist Alexandra Stiglmayer collected and published testimonies with Bosnian rape survivors first in German as Massenvergewaltigung: Krieg gegen die Frauen (Freiburg: Kore, 1993). It was revised and expanded in English as Mass Rape (Lincoln: University of Nebraska Press, 1994), with essays by Catharine A. MacKinnon, Susan Brownmiller, and others.

50. Hauser is a Swiss gynecologist who lived and worked in Germany at the time of the outbreak of the Yugoslav war. In April 1993 she opened, with the help of local experts, the therapy center Medica Zenica in the Bosnian town of Zenica to help raped women. For her work with women in crisis areas, she received many awards, in Germany and internationally (i.e., Woman of the Year award in 1993 from the German state television ARD; Right Livelihood Award in 2008).

51. Butalia, The Other Side of Silence, 200.

52. Tatjana Takševa, "Interview with Sabina," 18 July 2017. All interviews used in this article are in the possession of the authors at the time of publication. We wish to thank research assistant Ivana Amidzic for her help with transcribing and translating some of the interviews.

53. While most survivors continue to choose silence, there are some recorded testimonies on which earlier publications were based. See Stiglmayer, Mass Rape; Seada Vranić, Pred zidom šutnje (Breaking the Wall of Silence: The Voices of Raped Bosnia) (Zagreb: Antibarbarus, 1996); Leydesdorff, Surviving the Bosnian Genocide; Julie Mertus, Jasmina Tesanovic, Habiba Metikos, and Rada Boric, eds., The Suitcase: Refugee Voices from Bosnia and Croatia (Berkeley: University of California Press, 1997). Worth mentioning is also Alexandra Cavelius's Leila: Ein bosnisches Mädchen [Leila, a Bosnian girl] (Munich: Ullstein, 2000), based on the harrowing story of a teenage Bosnian girl and her survival of torture and sexual slavery at the hands of Muslim and Serb military forces. Unfortunately, it has not been translated into Bosnian or English.

54. "We Are Still Alive": Research on the Long-Term Consequences of War Rape and Coping Strategies of Survivors in Bosnia and Herzegovina (Zenica: Medica Zenica \& medica mondiale, 2014), 11 and 29, https://www.medicamondiale.org/fileadmin/redaktion/5_Service/Mediathek/Dok umente/English/Documentations_studies /141128_Research_We-Are-Still-Alive_CR-MedicaZenica_medica-mondiale.pdf.

55. Julia Garraio, "Interview with Gabriela Mischkowski," P@x-Online Bulletin: Sexual Violence in Armed Conflict 18 (January 2012): 8-11, here 8, https://www.ces.uc.pt/publicacoes/ p@x/pdf/P@x18en.pdf.

56. Ibid. 
57. "The ICTR in Brief," United Nations: International Residual Mechanism for Criminal Tribunals, unictr.irmct.org/en/tribunal.

58. Filip Rudic, Admir Muslimovic, Marija Ristic, and Sven Milekic, "Hague Tribunal Closes Down, Leaving Disputed Legacy," Balkan Insight.com, 21 December 2017, www.balkaninsight .com/en/article/hague-tribunal-closes-down-leaving-disputed-legacy-12-20-2017.

59. Ibid.

60. Antonio Sousa, “Editorial," P@x Online Bulletin: Sexual Violence in Armed Conflict 18 (January 2012), https://www.ces.uc.pt/publicacoes/p@x/pdf/P@x18en.pdf.

61. Judith Herman, Trauma and Recovery: The Aftermath of Violence-From Domestic Abuse to Political Terror (New York: Basic Books, 2015), 1. Originally published in 1997.

62. W. Hesford, "Reading Rape Stories: Material Rhetoric and the Trauma of Representation," College English 62 (1999): 192-221, here 203.

63. We acknowledge that the conditions and experiences of rape in conflict necessarily carry their particularities rooted in their respective contexts and that violence in war has "multiple facets" (Branche et al., "Writing the History of Rape," 4).

64. Elizabeth Swanson, "Rape, Representation, and the Endurance of Hegemonic Masculinity," Violence Against Women 25, no. 13 (2019): 1613-1630, here 1621.

65. Ibid.

66. Roger Woods, "Introduction: The Purposes and Problems of German Life Writing in the Twentieth Century," in German Life Writing in the Twentieth Century, eds. Birgit Dahlke, Dennis Tate, and Roger Woods. (Rochester: Camden House, 2010), 1-24, here 1.

67. Takševa, "Interview with Sabina."

68. Dominick LaCapra, Writing History, Writing Trauma (Baltimore: Johns Hopkins University Press, 2001), 142.

69. Takševa, "Interview with Azra," 20 July 2017.

70. Ibid.

71. Takševa, "Interview with Sabina."

72. Takševa, "Interview with L.O.," 18 July 2017.

73. Harun Cero, "Gebhardt: Saveznici masovno silovali Njemice” [Gebhardt: The Allies committed mass rapes in Germany], Aljazeera Balkans, 29 April 2015, http://balkans.aljazeera.net/ vijesti/gebhardt-saveznici-masovno-silovali-njemice.; “O ovome se malo pričalo: Nisu silovali samo vojnici Crvene armije" [Little was talked about this: Not only Red Army soldiers were raping], Blic RS, 3 April 2015, https://www.blic.rs/riznica/istorije/o-ovome-se-malo-pricalo-nisu-silovali-samo-vojnici-crvene-armije/0kbhsdg.; "Silovano oko 860,000 Njemica" [About 860,000 German women were raped], Novi, 13 April 2015, https://novi.ba/clanak/15134/12.

74. On 20 April 1945, Stalin finally issued an order to his troops to treat German civilians better (Beevor, The Fall, 413). However, his attitude toward rape was rather ambiguous. Although it was officially a crime in the Red Army, Stalin condoned it as a method of rewarding the soldiers. See Andrew Roberts, "Stalin's army of rapists: The brutal war crime that Russia and Germany tried to ignore," Daily Mail Online, 24 October 2008, https://www.dailymail .co.uk/news / article-1080493/Stalins-army-rapists-The-brutal-war-crime-Russia-Germanytried-ignore.html.

75. Ute Baur-Timmerbrink, Wir Besatzungskinder: Töchter und Söhne allieerter Soldaten erzählen [We children of the occupation: Daughters and sons of Allied soldiers tell their story] (Berlin: Ch. Links Verlag, 2015).

76. Mechthild Rawert estimates 250,000 children in Germany and a minimum of 20,000 children in Austria. See "Vorwort" [Preface], in Kleinau and Mochmann, Kinder des zweiten Weltkrieges, 9-10, here 9. It is virtually impossible to differentiate in the statistics between chil- 
dren born of consensual relationships and children born of rape given the complex nature of sexual violence in wars.

77. In Germany and Austria, collecting and researching stories about children of the occupation has resulted in important publications in recent years, such as Stelzl-Marx and Satjukow, Besatzungkinder; Silke Satjukow and Rainer Gries, "Bankerte!" Besatzungskinder in Deutschland nach 1945 ["Bastards!" Children of the occupation in Germany after 1945] (Frankfurt am Main: Campus Verlag, 2015); Kleinau and Mochmann, Kinder des zweiten Weltkrieges; Gebhardt, Wir Kinder der Gewalt: Wie Frauen und Familien bis heute unter den Folgen der Massenvergewaltigungen bei Kriegsende leiden [We children born of violence: How women and families still suffer from the mass rapes at the end of the war] (Munich: Deutsche Verlags-Anstalt, 2019). Gisela Heidenreich, Vom Krieg geboren: Europas verleugnete Kinder [Born of War: Europe's denied children] (Berlin: Ch. Links Verlag, 2017), looks at children born of World War II in several European countries. One also ought to mention the groundbreaking publication of the children's own narratives: Winfried Behlau, ed., Distelblüten: Russenkinder in Deutschland, translated into English by Ursula Scott as Thistleflowers: Russian Children in Germany (Ganderkesee: con-thor, 2015); Eleonore Dupuis, Befreiungskind [Child of the liberation] (Vienna: Edition Launigg, 2015).

78. R. Charli Carpenter gives an estimate between 400 and 600 children born of war in Bosnia, but this number, provided by doctors, could be higher. Forgetting Children Born of War: Setting the Human Rights Agenda in Bosnia and Beyond (New York: Columbia University Press, 2010), 23.

79. Branche et al., "Writing the History of Rape," 11.

80. Elazar Barkan and Belma Bećirbašić, "The Politics of Memory, Victimization, and Activism in Post-conflict Bosnia and Herzegovina," in Historical Justice and Memory, eds. Klaus Neumann and Janna Thompson (Madison: University of Wisconsin Press, 2015), 95-114, here 95.

81. Andreas Hamburger, "Genocidal Trauma: Individual and Social Consequences of Assault on the Mental and Physical Life of a Group," in Psychoanalysis and Holocaust Testimony: Unwanted Memories of Social Trauma, eds. Dori Laub and Andreas Hamburger (New York: Routledge, 2017), 66-91, here 83-84.

82. Cvetkovich, An Archive of Feelings. 